\title{
Metastatic Unresectable Malignant Neoplasm
}

National Cancer Institute

\section{Source}

National Cancer Institute. Metastatic Unresectable Malignant Neoplasm. NCI Thesaurus.

Code C153279.

A malignant neoplasm that has spread from its original site of growth to another anatomic site and is not amenable to surgical resection. 